American Journal of Applied Sciences 8 (10): 1041-1044, 2011

ISSN 1546-9239

(C) 2011 Science Publications

\title{
STATCOM Stabilizer based on Fuzzy Logic Control for Damping Power Oscillation
}

\author{
Prechanon Kumkratug \\ Department of Electrical Engineering, Faculty of Engineering at Si Racha, \\ Kasetsart University, 199 M.6, Tungsukhla, Si Racha, Chonburi, 20230, Thailand
}

\begin{abstract}
Problem statement: In power systems, there exists a continuous challenge to improve dynamic performance of power system. Approach: Static Synchronous Compensator (STATCOM) is a power electronic based device that has the capability of controlling the power flow through a line. This study applies the Static Synchronous Compensator (STATCOM) to control the power flow during dynamic period. To verify the effect of the STATCOM on dynamic performance, the mathematical model and control strategy of a STATCOM was needed to be presented. The converters of STATCOM were represented by variable voltage source with associate transformer leakage reactance and the voltage source and the reactance were transformed into current injection. The current injection model of STATCOM was modeled into power flow equation and thus it was used to determine control strategy. This study applies the fuzzy logic control to determine the control strategy of STATCOM. The swing curves of the three phase faulted power system without and with a STATCOM was tested and compared in various cases. Results: The swing curve of the system with STATCOM based fuzzy logic control had the less amplitude during the dynamic period. Conclusion: STATCOM can improve the dynamic performance of the system after disturbance.
\end{abstract}

Key words: Power system, fuzzy logic control, static synchronous compensator, FACTS devices, current injection, power flow, transient stability, voltage source

\section{INTRODUCTION}

Power system oscillation is one of the important aspects in modern power system. Currently, power engineers are much more concerned about stability problem due to blackout in Northeast United States, Scandinavia, England and Italy (Kumkratug, 2010; Padma and Rajaram, 2011; Osuwa and Igwiro, 2010; Kumkratug, 2011a). They have proposed many methods to improve stability of power system such as load shedding, Flexible AC Transmission System (FACTS), (Al-Husban, 2009; Kumkratug, 2011b; Magaji and Mustafa, 2009; Mustafa and Magaji, 2009; Zarate-Minano et al., 2010).

A Static Synchronous Compensator (STATCOM) is a member of the FACTS family that is connected in shunt with system. The STATCOM consists of a solid state voltage source converter with GTO thyristor switches or other high performance of semi-conductor and transformer. The STATCOM can electrically mimic reactor and capacitor by injecting a shunt current in quadrature with the line voltage. The reactive power (or current) of the STATCOM can be adjusted by controlling the magnitude and phase angle of the output voltage of the shunt converter (Al-Husban, 2009; Mustafa and Magaji, 2009).

This study presents the fuzzy logic control law of STATCOM. The mathematical model of power system with a STATCOM is systematically derived. The nonlinear control of fuzzy logic control is applied to determine the control strategy. The simulation results are tested on a sample system.

\section{MATERIALS AND METHODS}

Mathematical model: Figure 1a shows the single line diagram of Single Machine Infinite Bus (SMIB) system without a STATCOM and the corresponding equivalent circuit is shown in Fig. 1b.

Here $X_{1}$ is the equivalent reactance between the machine internal bus and the bus $m$ and $X_{2}$ is the equivalent reactance between bus $\mathrm{m}$ and the infinite bus. The generator is represented by a constant voltage source (E') behind transient reactance $\left(\mathrm{X}_{\mathrm{d}}{ }^{\prime}\right)$. 


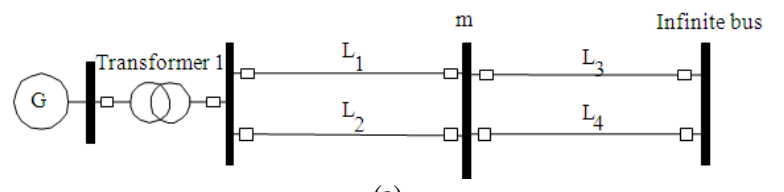

(a)

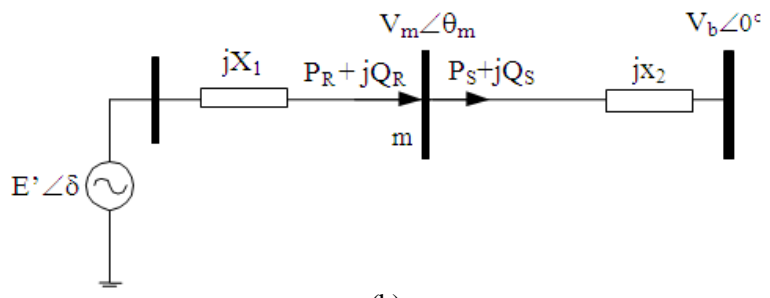

(b)

Fig. 1: Single machine infinite bus system (a) schematic diagram (b) equivalent circuit

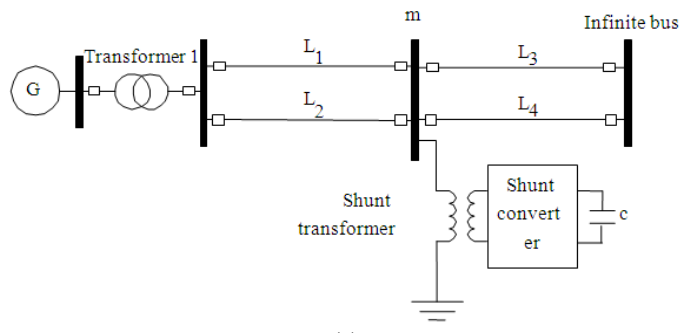

(a)

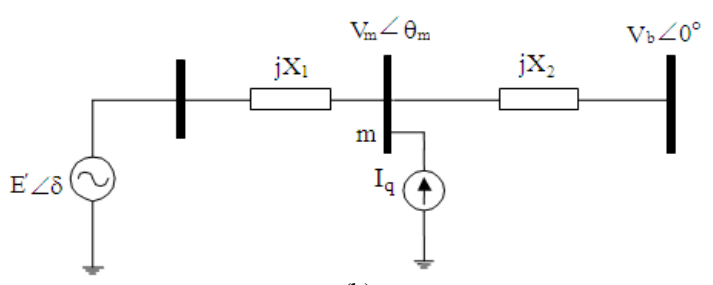

(b)

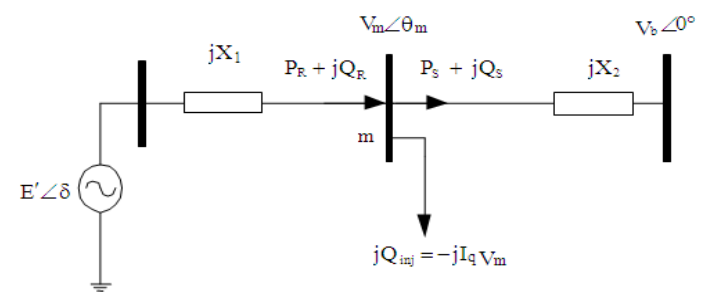

(c)

Fig. 2: Single machine infinite bus system with a STATCOM (a) schematic diagram (b) equivalent circuit of system with a STATCOM represented by a current injection model (c) equivalent circuit of system with a STATCOM represented by a load injection model

The active power balance at bus $\mathrm{m}$ is given by:
$\mathrm{P}_{\mathrm{R}}=\mathrm{P}_{\mathrm{S}}$

Here:

$$
P_{R}=\frac{E^{\prime} V_{m}}{X_{1}} \sin \left(\delta-\theta_{m}\right)
$$

And:

$$
\mathrm{P}_{\mathrm{S}}=\frac{\mathrm{V}_{\mathrm{m}} \mathrm{V}_{\mathrm{b}}}{\mathrm{X}_{2}} \sin \left(\theta_{\mathrm{m}}\right)
$$

After some mathematical manipulations of Eq. 1-3, the voltage angle at bus $\mathrm{m}$ is Eq. 4 :

$\theta_{\mathrm{m}}=\tan ^{-1}\left(\frac{\mathrm{E}^{\prime} \mathrm{X}_{2} \sin \delta}{\mathrm{E}^{\prime} \mathrm{X}_{2}}\right)$

The reactive power balance at bus $\mathrm{m}$ is given by:

$\mathrm{Q}_{\mathrm{R}}=\mathrm{Q}_{\mathrm{S}}$

Here:

$\mathrm{Q}_{\mathrm{R}}=\frac{\mathrm{E}^{\prime} \mathrm{V}_{\mathrm{m}}}{\mathrm{X}_{1}} \cos \left(\delta-\theta_{\mathrm{m}}\right)-\frac{\mathrm{V}_{\mathrm{m}}^{2}}{\mathrm{X}_{1}}$

And:

$\mathrm{Q}_{\mathrm{S}}=\frac{\mathrm{V}_{\mathrm{m}}^{2}}{\mathrm{X}_{2}}-\frac{\mathrm{V}_{\mathrm{m}} \mathrm{V}_{\mathrm{b}}}{\mathrm{X}_{2}} \cos \theta_{\mathrm{m}}$

After some mathematical manipulations of Eq. 5-7, the voltage magnitude at bus $\mathrm{m}$ is Eq. 8:

$V_{m}=\frac{E^{\prime} X_{2} \cos \left(\delta-\theta_{m}\right)+X_{1} V_{b} \cos \theta_{m}}{X_{1}+X_{2}}$

It can observe from the Fig. $1 \mathrm{~b}$ and Fig. $2 \mathrm{c}$ that the STACOM doesn't affect on the active power balance and then the voltage angle equation at bus doesn't change. However, the STATCOM affects on reactive power balance given by:

$\mathrm{Q}_{\mathrm{R}}=\mathrm{Q}_{\mathrm{S}}+\mathrm{Q}_{\mathrm{inj}}$

Here:

$\mathrm{Q}_{\text {inj }}=-\mathrm{V}_{\mathrm{m}} \mathrm{I}_{\mathrm{q}}$ 


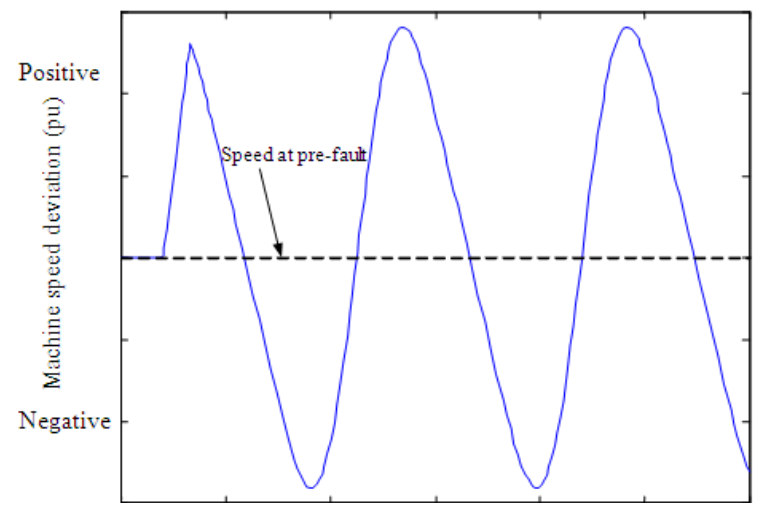

Fig. 3: Machine speed of system after disturbance

After some mathematical manipulations of Eq. 910 , the voltage magnitude at bus $m$ of the system with a STACOM is given by Eq. 11:

$$
\mathrm{V}_{\mathrm{m}}=\frac{\mathrm{E}^{\prime} \mathrm{X}_{2} \cos \left(\delta-\theta_{\mathrm{m}}\right)+\mathrm{X}_{1} \mathrm{~V}_{\mathrm{b}} \cos \theta_{\mathrm{m}}+\mathrm{V}_{\mathrm{m}} \mathrm{I}_{\mathrm{q}}}{\mathrm{X}_{1}+\mathrm{X}_{2}}
$$

It can be seen from Eq. 4, 8 and 11 that the parameter of STATCOM doesn't affect on line voltage angle but it affects on line voltage magnitude.

Fuzzy logic control: The dynamic equation of power system as shown in Fig. 2a can be expressed by following Eq. 12 and 13:

$\dot{\delta}=\omega$

$\dot{\omega}=\frac{1}{\mathrm{M}}\left[\mathrm{P}_{\mathrm{m}}-\mathrm{P}_{\mathrm{e}}\right]$

Here, $\delta, \omega, \mathrm{P}_{\mathrm{m}}, \mathrm{M}$ and $\mathrm{P}_{\mathrm{e}}$ are the rotor angle, speed, mechanical input power and moment of inertia electrical output power, respectively of machine.

Figure 3 shows the machine speed of system after disturbance by using Eq. 12-13. Figure 4 shows the input and the output fuzzy membership function based on fuzzy logic control, respectively. The machine speed at pre-fault is considered as reference at zero value $(\omega=$ 0 ). This study uses the rules based on human reasoning of Mamdani inference engine. Rules are defined as follows:

- If $\omega$ is positive big then $\mathrm{I}_{\mathrm{q}}$ is positive big

- If $\omega$ postive then $I_{q}$ is positive

- If $\omega$ zero then $I_{q}$ is zero

- If $\omega$ negative then $I_{q}$ is negative

- If $\omega$ negative big then $I_{q}$ is negative big

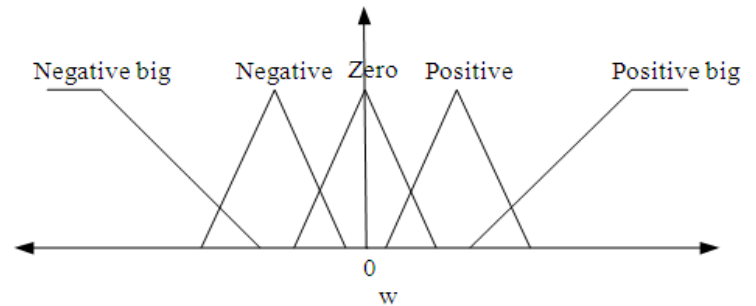

(a)

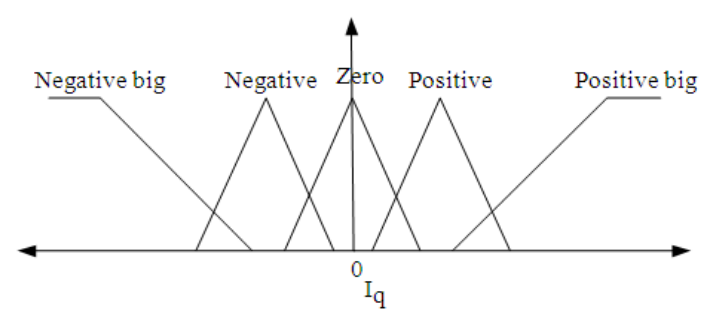

(b)

Fig. 4: Membership functions (a) Input (b) Output

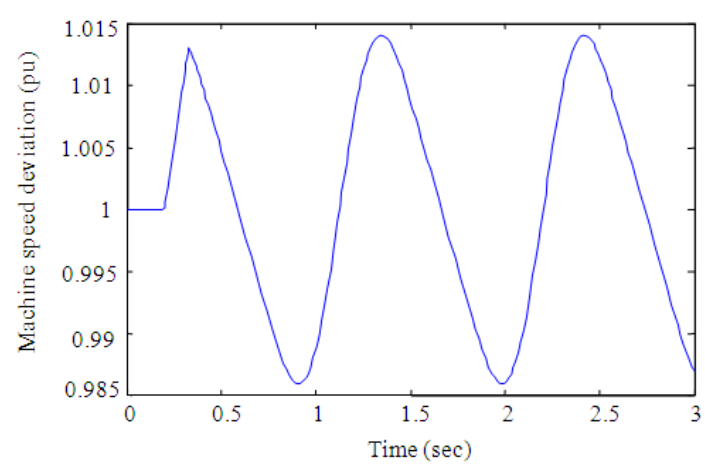

Fig. 5: Machine speed of sample system

\section{RESULTS}

The proposed control method is tested on sample system equipped with a STATCOM based fuzzy logic control strategy. The single line diagram of sample system is shown in Fig. 2a. The system parameters are:

$$
\begin{gathered}
\mathrm{H}=5, \mathrm{X}_{\mathrm{t}}=0.1 \mathrm{pu}, \mathrm{X}_{\mathrm{d}}{ }_{\mathrm{d}}=0.3 \mathrm{pu}, \mathrm{X}_{\mathrm{L} 1}=0.4 \mathrm{pu}, \mathrm{X}_{\mathrm{L} 2}=0.4 \mathrm{pu}, \\
\mathrm{X}_{\mathrm{L} 3}=0.4 \mathrm{pu}, \mathrm{X}_{\mathrm{L} 4}=0.4 \mathrm{pu}, \mathrm{P}_{\mathrm{m}}=1.0 \mathrm{pu}, \mathrm{E}_{\mathrm{q}}=1.23 \mathrm{pu}
\end{gathered}
$$

It is considered that 3 phase fault appears at line 1 near bus $\mathrm{m}$ for $130 \mathrm{~ms}$ and then it is cleared by opening both circuit breakers. Figure 5 shows the machine speed of sample system without FACTS devices for generating the fuzzy membership of input $\omega$ and output $I_{q}$ as shown in Fig. 6a-b, respectively. Figure 7 shows the swing curve of the system without and with a STATCOM. 


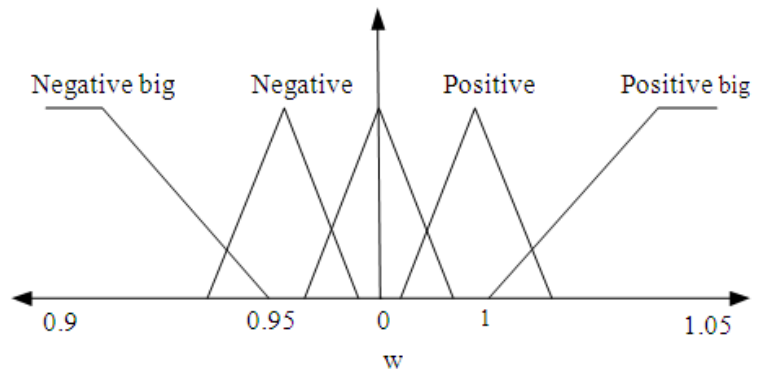

(a)

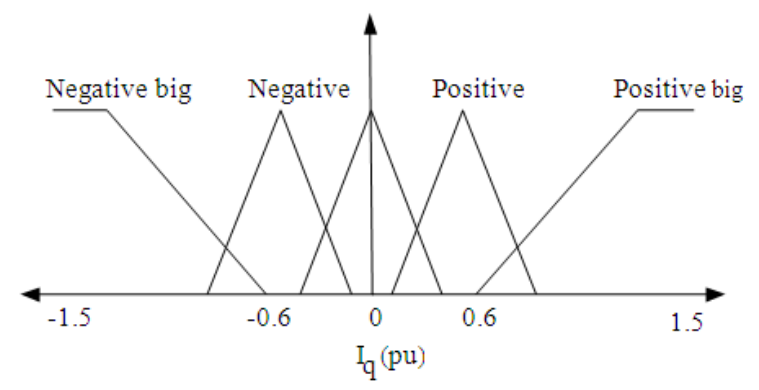

(b)

Fig. 6: Membership functions of fuzzy membership (a) input (b) output

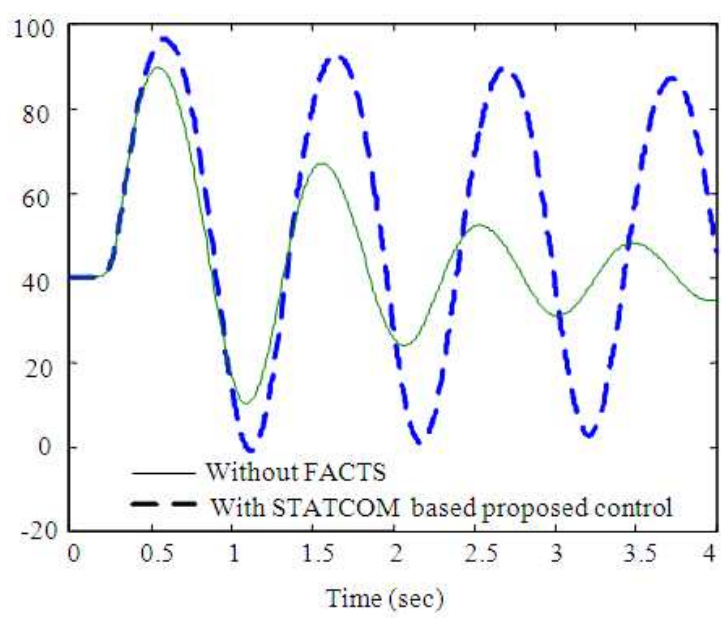

Fig. 7: Swing curve of the system without and with a STATCOM

\section{DISCUSSION}

It can be observed from the simulation results that the STATCOM based fuzzy logic control can improve dynamic performance of the system. The maximum and minimum machine rotor angles are around 98.74 and maximum and minimum machine rotor angles are improved to around 87.35 and 9.28 , respectively.

\section{CONCLUSION}

This study presented the method of improving dynamic performance of power system using a STATCOM. The mathematical model of power system equipped with a STATCOM was systematically derived. It was found that a STATCOM affects on the line voltage. The stability of the power system can be controlled by a STACOM. This study applied fuzzy logic control to determine the control law of STATCOM. The simulation results are tested on a sample system. From the simulation results, it indicates that a STATCOM based fuzzy logic control can improve the dynamic performance of the system.

\section{REFERENCES}

Al-Husban, A.N., 2009. An eigenstructure assignment for a static synchronous compensator. Am. J. Eng. Applied Sci., 2: 812-816. DOI: 10.3844/ajeassp.2009.812.816

Kumkratug, P., 2010. Application of interline power flow controller to increase transient stability of power system. J. Comput. Sci., 6: 1490-1493. DOI: 10.3844/jcssp.2010.1484.1487

Kumkratug, P., 2011a. Nonlinear control design of shunt flexible AC transmission system devices for damping power system oscillation. J. Comput. Sci., 7: 854-858. DOI: $10.3844 /$ jcssp.2011.854.858

Kumkratug, P., 2011b. Optimal control design of static synchronous series compensator for damping power system oscillation. J. Comput. Sci., 7: 844848. DOI: $10.3844 /$ jcssp.2011.844.848

Magaji, M. and M.W. Mustafa, 2009. Optimal thyristor control series capacitor neuro-controller for damping oscillations. J. Comput. Sci., 5: 980-987. DOI: 10.3844 jcssp.2009.980.987

Mustafa, M.W. and N. Magaji, 2009. Optimal location of static var compensator device for damping oscillations. Am. J. Eng. Applied Sci., 2: 353-359. DOI: 10.3844/ajeassp.2009.353.359

Osuwa, J.C. and E.C. Igwiro, 2010. Uninterruptible power supply using solar rechargeable battery. Physics. Int., 1: 77-82. DOI: 10.3844/pisp.2010.77.82.

Padma, S. and M. Rajaram, 2011. Fuzzy logic controller for static synchronous series compensator with energy storage system for transient stability analysis. J. Computer Sci., 7: 859-864. DOI: 10.3844/jcssp.2011.859.864

Zarate-Minano, R., T. Van Custsem, F., Milano and A.J. Conejo, 2010. Sexuring transient stability using time domain simulations within an optimal power flow. IEEE Trans. Power Syst., 5: 243-253, DOI: 10.1109/TPWRS.2009.203069. 